\title{
Histological observations on foetal resorption in copper-deficient rats
}

\author{
By J. McC. HOWELL AND G. A. HALL \\ Department of Veterinary Pathology, University of Liverpool
}

(Received 25 April I968-Accepted 20 September 1968)

\begin{abstract}
1. Twenty-six rats were fed a diet of milk treated with hydrogen sulphide together with copper-free mineral and vitamin supplements; fourteen of these rats were used as controls and were given $500 \mu \mathrm{g}$ Cu per rat per week. Seven other rats were fed a commercial diet.

2. Mating to stock males commenced when the rats had been fed the diets for 6 weeks, and they were killed from the roth to the 16 th days of pregnancy.

3. The average number of placental sites was 17.9 in stock, 10.4 in control and $1 \mathrm{I} .8$ in deficient rats. Spontaneously resorbing sites were seen in three stock, seven control and six deficient animals.

4. The foetuses of the stock and control animals grew normally but in the $\mathrm{Cu}$-deficient rats normal development ceased on the $13^{\text {th }}$ day of pregnancy when the foetal tissues were seen to be disintegrating. Necrosis of the placenta was seen on the 15 th day of pregnancy and until then blood islands were present.

5. Lesions were not seen in the maternal mammary glands, ovaries or pituitary glands.
\end{abstract}

Copper-deficient rats conceive but resorb their foetuses (Dutt \& Mills, I960; Hall $\&$ Howell, 1969). The sequence of events which occurs during resorption had not been studied and it was not known whether the foetus or placenta was the primary site of damage. The work reported here records the development of lesions in the reproductive tract of pregnant $\mathrm{Cu}$-deficient rats.

\section{EXPERIMENTAL}

Animals and diet. Hooded rats were used and at the start of the experiment they were between 9 and I I weeks old. Seven rats were kept in stock cages and fed a standard laboratory rat diet. Twenty-six rats were kept in Perspex and Pyrex glass-rod cages, modified from those described by McCosker (1967) and fed milk treated with hydrogen sulphide supplemented with $\mathrm{Cu}$-free minerals and vitamins by the procedure described by Hall \& Howell (1969), the $\alpha$-tocopheryl acetate supplement being given in two doses of $\mathrm{r} \cdot 2 \mathrm{mg}$ each week. Fourteen of these rats acted as controls and received roo $\mu \mathrm{g}$ of $\mathrm{Cu}$ given as copper sulphate mixed with the minerals and vitamins on 5 days of the week.

Mating of females. Vaginal smears were prepared daily throughout the experiment. Mating commenced when the rats had been fed the diet for 6 weeks. A stock male was introduced into the cage of a female in oestrus and removed the following morning. The day on which spermatozoa were found in the vagina was called the Ist day of pregnancy.

Examination of tissues. Rats were killed on the roth-r6th days of pregnancy inclusive. The reproductive tract was examined and photographed. Uterus, ovaries and 
mammary gland were fixed in Bouin's fluid and pituitaries were fixed in formolsublimate. Tissues were embedded in paraffin wax, sections were cut at $5 \mu \mathrm{m}$ and stained with haematoxylin (Mayer's haemalum) and eosin. The pituitaries were also stained by the periodic acid-Schiff procedure as described by Purves \& Griesbach (1951).

\section{RESULTS}

The uterus. The number of rats, the number of placental sites examined and the number of lesions are given in Table 1 . The seven stock rats had an average of $17 \cdot 9$ placental sites, fourteen controls had an average of 10.4 and twelve deficient rats had

Table I. Number of placental sites and lesions found in the three groups of rats examined from the Ioth to the $\mathrm{I} 6$ th day of pregnancy

\begin{tabular}{|c|c|c|c|c|c|c|}
\hline \multirow[b]{2}{*}{$\begin{array}{c}\text { Day of } \\
\text { pregnancy }\end{array}$} & \multirow[b]{2}{*}{ Type of rat } & \multicolumn{4}{|c|}{ No. of placental sites } & \multirow[b]{2}{*}{$\begin{array}{l}\text { No. of rats } \\
\text { (in parentheses) } \\
\text { and total no. of } \\
\text { placentas } \\
\text { examined }\end{array}$} \\
\hline & & $\begin{array}{l}\text { Healthy } \\
\text { foetus } \\
\text { and } \\
\text { placenta }\end{array}$ & $\begin{array}{c}\text { Dead } \\
\text { foetus, } \\
\text { normal } \\
\text { placenta }\end{array}$ & $\begin{array}{c}\text { Dead } \\
\text { foetus, } \\
\text { necrotic } \\
\text { placenta }\end{array}$ & $\begin{array}{l}\text { Spontaneous } \\
\text { resorption }\end{array}$ & \\
\hline Io & $\begin{array}{l}\text { Stock } \\
\text { Control } \\
\text { Deficient }\end{array}$ & $\begin{array}{l}\text { r5 } \\
\text { I5 } \\
\text { I3 }\end{array}$ & - & E & E & $\begin{array}{l}\text { (I) } 15 \\
\text { (2) } 15 \\
\text { (I) } 13\end{array}$ \\
\hline I I & $\begin{array}{l}\text { Stock } \\
\text { Control } \\
\text { Deficient }\end{array}$ & $\begin{array}{l}17 \\
27 \\
32\end{array}$ & $\begin{array}{l}- \\
-\end{array}$ & $\begin{array}{l}- \\
-\end{array}$ & E & $\begin{array}{l}\text { (I) } 17 \\
\text { (2) } 27 \\
\text { (3) } 32\end{array}$ \\
\hline $\mathrm{I} 2$ & $\begin{array}{l}\text { Stock } \\
\text { Control } \\
\text { Deficient }\end{array}$ & $\begin{array}{l}13 \\
25 \\
25\end{array}$ & E & E & $\frac{-}{2}$ & $\begin{array}{l}\text { (I) } 13 \\
\text { (2) } 25 \\
\text { (2) } 27\end{array}$ \\
\hline $\mathbf{I 3}$ & $\begin{array}{l}\text { Stock } \\
\text { Control } \\
\text { Deficient }\end{array}$ & $\begin{array}{l}14 \\
19 \\
-\end{array}$ & $\frac{-}{10}$ & - & $\begin{array}{l}\mathbf{I} \\
3 \\
\mathrm{I}\end{array}$ & $\begin{array}{l}\text { (I) } 15 \\
\text { (2) } 22 \\
\text { (I) I I }\end{array}$ \\
\hline 14 & $\begin{array}{l}\text { Stock } \\
\text { Control } \\
\text { Deficient }\end{array}$ & $\begin{array}{l}\text { I6 } \\
\text { ro } \\
-\end{array}$ & $\begin{array}{l}- \\
1 \\
15\end{array}$ & - & $\begin{array}{l}3 \\
6 \\
4\end{array}$ & $\begin{array}{l}\text { (I) } 19 \\
\text { (2) } 17 \\
\text { (2) } 19\end{array}$ \\
\hline 15 & $\begin{array}{l}\text { Stock } \\
\text { Control } \\
\text { Deficient }\end{array}$ & $\begin{array}{l}13 \\
15 \\
\end{array}$ & E & $\overline{-}$ & $\begin{array}{r}- \\
5 \\
2\end{array}$ & $\begin{array}{l}\text { (I) } 13 \\
\text { (2) } 20 \\
\text { (I) } 15\end{array}$ \\
\hline I 6 & $\begin{array}{l}\text { Stock } \\
\text { Control } \\
\text { Deficient }\end{array}$ & $\begin{array}{l}\text { II } \\
\text { I6 } \\
\end{array}$ & - & $\begin{array}{l}- \\
\text { I9 }\end{array}$ & $\begin{array}{l}\text { I } \\
3 \\
5\end{array}$ & $\begin{array}{l}\text { (I) } 12 \\
\text { (2) } 19 \\
\text { (2) } 24\end{array}$ \\
\hline
\end{tabular}

an average of $\mathrm{II}_{\mathrm{I}} \cdot 8$ placental sites. Three of the stock rats had five sites in which spontaneous resorptions had occurred, seventeen similar sites were seen in seven control rats and fourteen were seen in six deficient rats. Spontaneous resorption was not diagnosed before the I2th day of pregnancy; it was seen macroscopically as a small nodule in the uterine wall. Histologically much necrosis was present in the nodule and the only recognizable tissue was maternal decidua.

In all groups of rats, blastocysts had implanted and foetuses and placentas developed normally until the $\mathrm{I}^{\text {th }}$ day of pregnancy. On this day and thereafter the $\mathrm{Cu}$-deficient rats were abnormal (Table I). On the $13^{\text {th }}$ day the foetuses of the Cu-deficient rats were smaller than those of the control and stock rats (Pl. I $a, b)$ and histologically 
pyknosis and karyorrhexis were seen in foetal tissues (Pl. I $c$ and Table I). On the I $4^{\text {th }}$ day the foetal tissues were disintegrating but the placentas were still intact and contained haemopoietic tissue (Pl. I $d$ and Table I). In the Cu-deficient rats killed on the 15 th and I 6 th days of pregnancy the surface of the placental disc and the yolk sac wall had become necrotic and the foetuses were completely disrupted (Pl. $2 a, b$ and Table I).

Mammary gland, ovary and pituitary. Mammary glands, ovaries and pituitary glands were examined from all the adult rats. Deviations from the normal were not observed in any of the groups of rats.

\section{DISCUSSION}

Foetal death may be the result of changes which are initiated either in the placenta, as is typical of vitamin A deficiency (Howell, Thompson \& Pitt, 1964), or in the foetus, as occurs in vitamin $\mathrm{E}$ deficiency (Evans \& Burr, 1927; Urner, I93I). The result of $\mathrm{Cu}$ deficiency in the pregnant rat resembled vitamin $\mathrm{E}$ deficiency in that the primary site of damage was the foetus. However, the details of the lesions in $\mathrm{Cu}$ and vitamin $\mathrm{E}$ deficiency are different. There are some differences in the recorded details of the changes in vitamin E-deficient pregnant rats and these will be briefly reviewed. Evans \& Burr (1927) found that the development of the foetuses of vitamin E-deficient rats was retarded until their death during the 13 th day of pregnancy. However, Urner (193I) did not find retardation of development of the embryo, but from the roth day onwards foetal mesenchyme was rarefied, pyknotic nuclei were seen on the I2th day, indicating foetal death, and embryos were not grossly visible after the i2th day. Evans \& Burr (I927) did not record placental necrosis until the 20th day of pregnancy, but Urner (193I) found necrosis of the foetal surface of the placenta at the 13 th day and the whole placenta was destroyed and cast into the lumen of the uterus by the 17th or 18th day. Both Evans \& Burr (1927) and Urner (193I) agree that important changes were seen in mesodermal blood islands from the time of their appearance at the Ioth day.

We did not find retardation of foetal development, and the first lesion seen was necrosis of foetal cells at the $13^{\text {th }}$ day of pregnancy (PI. i $c$ and Table I). Placental

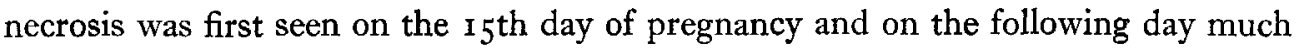
of the placental tissue was necrotic (P1.2a and Table $\mathrm{I}$ ). This sequence of events is closer to those seen by Urner (193I) than to those seen by Evans \& Burr (1927). Probably the most significant difference between our findings in the pregnant uteri of $\mathrm{Cu}$-deficient rats and those of vitamin $\mathrm{E}$ deficiency is that in our rats the mesodermal blood islands were present until the placenta became necrotic (Pl. I $d$ ). Furthermore, 'brown uterus' which is a characteristic of vitamin E deficiency has never been seen in our rats even when the uteri were inspected under ultraviolet light (see Moore \& Wang, I947).

The average number of placental sites was lower in the rats fed the milk than in the animals fed the stock diet. However, there was little difference between the average number of placental sites in the deficient and control groups. $\mathrm{Cu}$ deficiency did not appear to inhibit conception. 
Five per cent of the placental sites in the stock rats were spontaneous resorptions, whereas both the control and deficient rats had 10\% of spontaneous resorptions. This phenomenon had been seen previously in rats used in reproductive studies (Howell et al. 1964), and Telford, Woodruff \& Linford (1962) stated that 6-12\% of all implantations in rats terminated in resorptions. The size and histological appearance of the lesion indicated that it had occurred during early development. It did not resemble the lesion due to $\mathrm{Cu}$ deficiency for in these rats even at the I6th day of pregnancy histological evidence of necrotic foetal tissue could still be seen.

We wish to thank Professor D. L. Hughes for advice and encouragement; Mrs M. W. Harling, AIMLT, Miss A. Ronald and Mrs C. Savage for technical assistance, and Mr G. Weston, FIMLT and Mr E. O'Neill for the photographs. G. A. H. was an Agricultural Research Council postgraduate research student. The work was supported by a grant from the Agricultural Research Council.

\section{REFERENCES}

Dutt, B. \& Mills, C. F. (1960). F. comp. Path. 7o, 120.

Evans, H. M. \& Burr, G. O. (1927). Mem. Univ. Calif. 8, г.

Hall, G. A. \& Howell, J. McC. (r969). Br. F. Nutr. 23, 41.

Howell, J. McC., Thompson, J. N. \& Pitt, G. A. J. (I964). F. Reprod. Fertil. 7, 25 I.

McCosker, P. J. (1967). Br. F. Nutr. 21, 23 I.

Moore, T. \& Wang, Y. C. (1947). Br. F. Nutr. I, 53 .

Purves, H. D. \& Griesbach, W. E. (195I). Endocrinology 49, 244.

Telford, I. R., Woodruff, C. S. \& Linford, R. H. (1962). Am. F. Anat. 110, 29.

Unner, J. A. (193I). Anat. Rec. 50, 175.

\section{EXPLANATION OF PLATES}

\section{PLATE I}

Photographs $a$ and $b$ are of longitudinal sections of the fixed uterus of rats killed on the $x_{3}$ th day of pregnancy; the scales are in $\mathrm{mm} . c$ and $d$ are histological sections stained by haematoxylin and eosin.

(a) Placentas and foetuses from a Cu-deficient rat. Placentas are normal but foetuses are small.

(b) Placentas and foetuses from a control rat. The structures are normal.

(c) Thirteen-day-old foetus from a Cu-deficient rat. Pyknotic and fragmented nuclei can be seen in the bottom half of the figure.

(d) Fourteen-day-old placental disc from a Cu-deficient rat. Mesodermal blood islands are present in the yolk sac at $A$, and in the placental labyrinth at B. Healthy cells of Reichert's membrane can be seen on the surface of the placental disc.

Plate 2

Photographs of longitudinal sections of the fixed uterus of rats killed on the 16 th day of pregnancy. The scale is in $\mathrm{mm}$.

(a) Placental sites from a Cu-deficient rat. The placenta is necrotic, foetal remnants cannot be identified.

(b) Placental sites from a control rat. The structures are normal. 

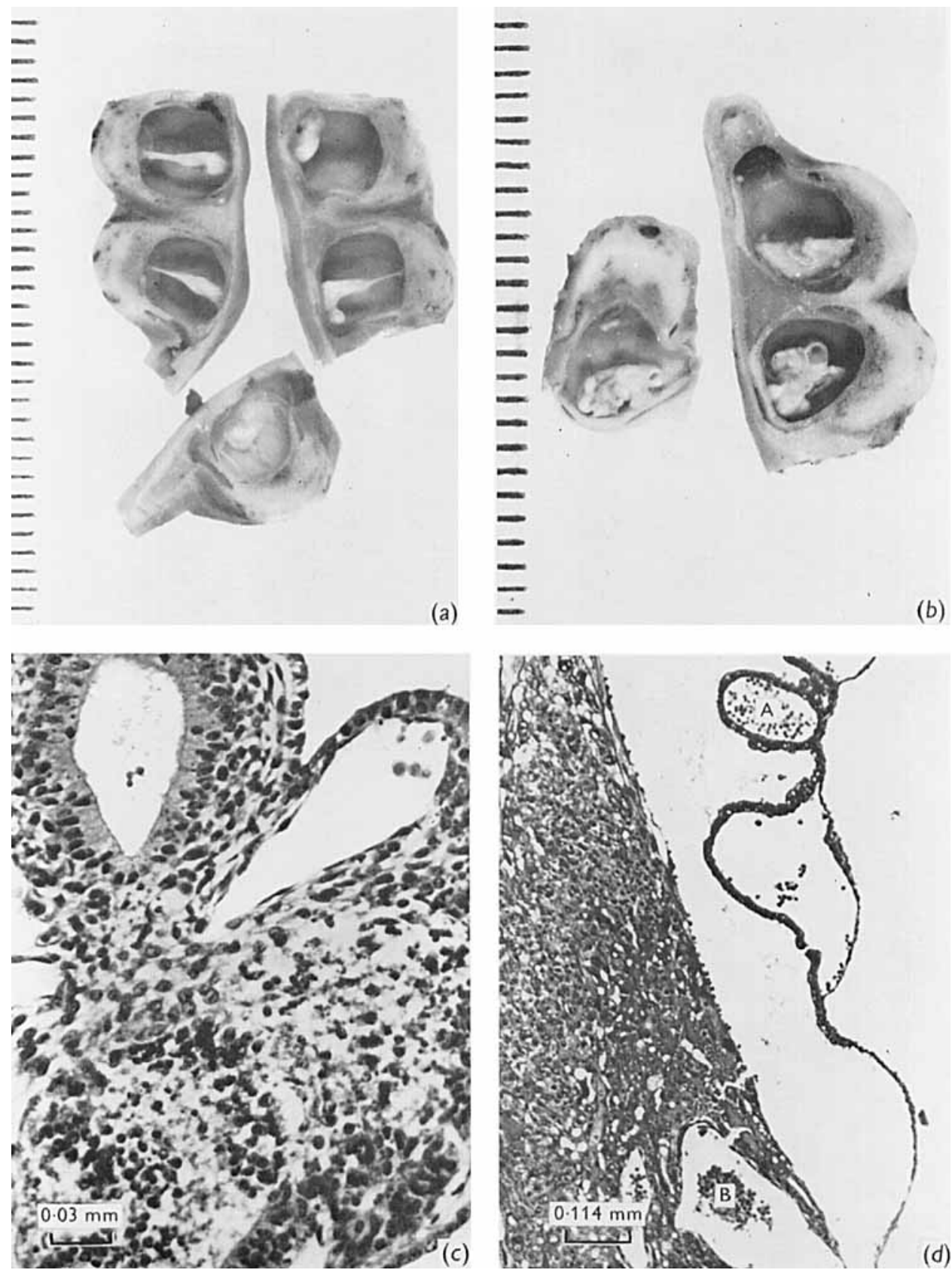

J McC. HOWELL ANd G. A. HALL 
British Fournal of Nutrition, Vol. 23, No. I

Plate 2
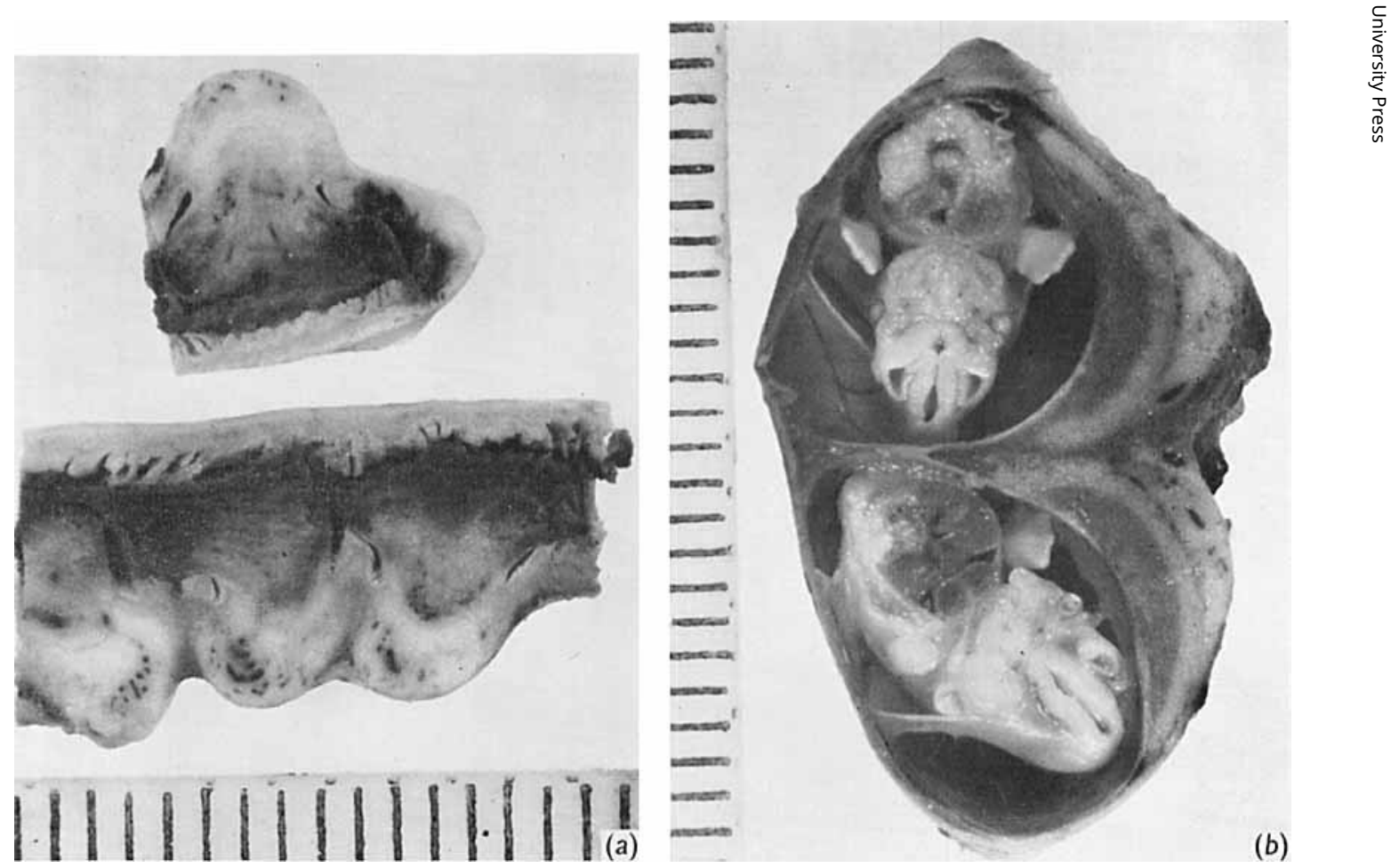

(b)

J. MCC. HOWELI AND G. A. HALL 